\title{
CORFESPONDEINOE.
}

\section{WHAT IS AN ERRATIC?}

Sir,-I am constrained to ask the above question in consequence of the appearance, in the Records of the Geological Survey of India (vol. x. p. 223), of some critical remarks by Mr. Theobald, upon my previous reference to the "Erratics" of the Upper Punjab in the same volume (p. 123).

In these remarks Mr. Theobald restricts and applies the term "Erratics" exclusively to certain blocks supposed to have been ice-transported, advocating the idea also (vide foot-note) that the word is only applicable in describing recent phases of geology.

Every field geologist must have observed travelled rock-fragments, the connexion of which with glaciation was not apparent, and to which the comprehensive term "Erratic" would be perfectly applicable. Such transported fragments might have come from some neighbouring mountain, or have been transported by a large river, or drifted by a marine current, or ice might have moved them. In all these cases I hold that the fragments would be truly erratics, no matter at what period of geological history they wandered; also that glacial erratics may be included in the general term.

Chalk flints are found in the shore deposits of the South of Ireland. They may have come from France, or the South of England, from Antrim, or from unknown Chalk beds beneath the English Channel, but there is no evidence that they have been transported by ice. The materials of the Chesil Bank are accumulated by marine currents. The agency which enclosed Wicklow granite masses far within the Carboniferous Limestone of the County Dublin; or the great blocks of granite in a flow of Deccan Trap near Mundlaisir, on the Nerbudda, in India, are unknown: but are not these as genuinely erratics as any ice-borne blocks? If not erratics, what else are these travelled fragments to be called?

'The erratics of the Upper Punjab are of various kinds. One group of them dates very far back; these are all fragments of crystalline rocks, including many of red granite from an unknown source, and they occur imbedded in the geological series of the Salt Range, at every stage from pre-Silurian to latest Tertiary or Recent. Another group is of Himalayan origin; these have been transported from the north during Tertiary, post-Tertiary, and Recent periods, and are still travelling from the same direction: they include a great variety of Himalayan rocks. Yet another group comprises large angular and sub-angular blocks of Himalayan gneiss, granite, limestone, etc., which are supposed to have been carried by floating-ice. Nothing has yet been advanced to connect them with glaciation of the immediate localities in which they are found.

Some very large angular, red granite erratics, at considerable elevations on the Salt Range, and resting on different strata, are probably also attributable to flotation by means of ice. The best known of these is the Khewra Erratic. 
Other smaller, rounded, erratic boulders of red granite, locally numerous on or near the eastern Salt Range, but not entirely absent to the west, are supposed by me to have been mainly released by denudation from a Boulder-clay of probably Cretaceous age, which only occurs in the eastern part of this range. Anong these latter boulders one has been found (not in situ) bearing marks of glacial smoothing and striation.

With regard to both these rounded erratic boulders and the larger angular blocks, it is a question of interest, but of considerable difficulty, to decide by what means they were transported. The largest have no representatives as to size in the neighbouring Cretaceous (?) boulder bed, the fragments in which are usually rounded. Mr. Theobald suggests as their source a Palwozoic boulder zone of the range, and their derivation thence by weathering in sitú ; but this is impossible, for the Palæozoic boulder beds referred to never existed in the eastern Salt Range, or in the vicinity of these blocks ! They may therefore have been transported, as well as the northern ones, by floating-ice.

The smaller rounded and glaciated boulder just now mentioned would suggest Cretaceous glacial conditions with some probability, had it been found in situ. As it occurred in a wall (though near the boulder bed), its scoring and smoothing may have taken place either before or after its removal from that bed, supposing that it ever was included therein-a point incapable of proof, but open to conjecture.

At whatever period this particular boulder became glaciated, the fact suggests that any of the similar boulders about the Salt Range may have been originally glacial erratics: also that glacial conditions may have prevailed during any period to which the deposition of these boulders can be traced, from Palæozoic to Recent.

Rather than adrait a possibility of connexion between recent icework and the occurrence of these smaller granite erratics, Mr. Theobald prefers to assert their derivation, proximately from the Cretaceous Boulder-clay, but more immediately from weathering of the latest Tertiary conglomerates, because in a few instances he has found blocks of red granite in the last-named beds. This view I consider is untenable for two reasons, first on account of the number of the red granite recent erratics, next because the general parallelism pervading the whole of the eastern Salt Range series, from the oldest beds upwards, involves the Cretaceous Boulder-clay having been buried under many hundreds of feet of earlier Tertiary strata at the time when the few granite boulders of the uppermost Tertiary conglomerates were enclosed. ${ }^{1}$

From the whole of the facts regarding these red granite erratics, large and small, I think the fair inference is that red granitic rocky ground, lying probably to the south of the Salt Range, was being

1 There is some indication of a break in this Tertiary series, for apparently rolled fragments of Nummulitic Limestone are found in it at various scattered horizons, but the beds are all parallel. And there is no evidence that any rock of the Salt Range older than Nummulitic was being eroded during Tertiary deposition. The Cretaceous (?) Olive group is, however, older than the Nummulitic, and ought to have been covered duriug deposition of any subsequent beds. 
denuded and furnishing erratics, during the deposition of the whole Salt Range series; and further, that towards the later period (if not before) glacial conditions of the granitic region enabled masses of this rock to be floated to the Salt Range area by the agency of ice; there to undergo, in varying degrees, the usual operations of atmospheric denudation.

A. B. WYNNE.

CAMP Hazara, January 1, 1878.

MR. S. V. WOOD, JUN., IN REPLY TO DR. JAMES GEIKIE.

SrR,-Mr. James Geikie has not in his article in your last Number put the questions in issue between us so incisively as I could have wished.

1. I have never denied that land-ice erodes more in some places than it does in others. What I say is that if the great basin of the St. Lawrence has been eroded by this agency, all land surfaces must have perished in the process.

2. I have never denied that some moraine accumulates beneath ice. What $I$ say is that nearly all of it travels out to the ice termination. If it does not, how can valleys and basins be eroded by ice? If the bulk of what is degraded remains beneath the ice, no basin can result; for the moraine would to the same extent supply the place of the rocks degraded. It is only near the termination of the glacier that any considerable quantity of the moraine accumulates beneath the ice. This (as distinguished from the first accumulated portion of it, which resting on the middle glacial for the most part, though not always, was formed by the dropping of the moraine from floe-ice) I consider to have been the origin of that later part of the chalky clay which covers Lincolnshire, Huntingdonsbire, Cambridgeshire, and the adjoining district, accumulated in this way when the glacier which I have described as coming southwards over Lincolnshire terminated in the sea some twenty or thirty miles west of the Fen boundary; as well as of that which forms the basement clay of Holderness, which accumulated from an arm of this glacier that came through the Humber. All this moraine, as I hope some day to show in detail, was, except in two or three limited spots, left beneath the sea as the ice wasted away. The part in Holderness being followed by the depression northwards which brought over the Shap blocks, was succeeded uninterruptedly by another deposit of material from a different source, the purple clay; while the rest being in shallow water emerged before any such new deposit could form over it.

3. Mr. Geikie speaks thus of sands escaping the action of the overriding ice, viz.: "Where the gradually decreasing ice-sheet crawled slowly to its termination, we discover considerable accumulations of Till, resting upon apparently undisturbed beds of gravel, sand, and clay"; and again he says, "That an ice-sheet does under certain conditions ride over incoherent deposits of gravel, sand, silt, clay, and peat without entirely obliterating them."

Possibly the latter of these two statements may to some extent be 